\title{
Effects of landscape positions on soil physicochemical properties at Shenkolla Watershed, South Central Ethiopia
}

\author{
Belayneh Bufebo ${ }^{1,2^{*} \mathbb{D}}$, Eyasu Elias ${ }^{2}$ and Getachew Agegnehu ${ }^{3}$
}

\begin{abstract}
Background: Understanding the effects of landscape positions on soil physicochemical properties is crucial for improving the soil productivity and to ensure the environmental sustainability. Three land use types forest land, grazing land and cultivated land all within upper, middle and lower landscape positions were selected to determine the effects of landscape positions, land use types and their interaction effects on soil physicochemical properties. Twenty seven soil samples were collected from lower landscape, middle landscape and upper landscape positions at the depth of $0-20 \mathrm{~cm}$ in nine replications. In addition, undisturbed soil samples were taken using core sampler from each land use type under upper, middle and lower landscape positions for the ascertainment of bulk density and water retentive capacity. The analysis of variance (ANOVA) was applied to determine variations in soil parameters among landscape positions and land use types. A Generalized Linear Models (GLMs) analysis was conducted to determine the influence of independent (fixed) factors, on the soil properties (response variables). Treatment means comparison was determined using the Least Significant Difference (LSD) at 0.05 level of significances.
\end{abstract}

Results: The result indicated that among the soil properties sand ( $p<0.001)$, silt $(p<0.001)$, clay $(p<0.001)$, bulk density $(p<0.01)$, water holding capacity at FC $(p<0.001)$, water retention at PWP $(p<0.01)$, Available water content (AWC) $(p<0.01)$, soil reaction ( $p H)(p<0.05)$, Soil organic carbon (SOC\%) $(p<0.01)$, Total nitrogen (TN\%) $(p<0.01)$, available phosphorus $(p<0.05)$ and CEC $(p<0.001)$ have shown a significant variation among the landscape categories. Similarly, variation of sand ( $p<0.001)$, silt $(p<0.001)$, clay $(p<0.001)$, bulk density $(p<0.01)$, water holding capacity at FC $(p<0.001)$, water retention at PWP $(p<0.001)$, Available water content (AWC) $(p<0.01)$, soil reaction (pH) $(p<0.01)$, SOC ( $p<0.01)$, TN $(p<0.001)$ available phosphorus (AP) $(p<0.001)$ and CEC $(p<0.001)$ were also statistically significant among the land use types. Moreover, lower landscape position and forest land had high mean value of SOC, TN, AP, CEC, EB (exchangeable bases), and available micronutrients, whereas upper landscape position and intensively cultivated land had low mean value of SOC, TN, AP, CEC, EB (exchangeable bases), and available micronutrients.

Conclusion: Landscape positions, land use types and interaction effects of landscape position and land use types $\left(L S P^{*} \mathrm{LU}\right)$ significantly affected soil properties. Soil with best quality was found in lower landscape position and forest land, while less quality of soil was found in upper landscape position and cultivated land. Thus, efforts should be made to improve the quality of soil under upper landscape position and cultivated land using biological and physical soil conservation measures.

Keywords: Conservation, Landscape position, Management practices, Physicochemical property, Soil quality

\footnotetext{
*Correspondence: belaytumma@gmail.com

1 Department of Natural Resource Management, Wachemo University,

P.O. Box 667, Hosanna, Ethiopia

Full list of author information is available at the end of the article
}

\section{Background}

Soil's physical and chemical properties are the result of the interaction among the soil forming factors and processes, hence, making soil to be heterogeneous (Lawal 
et al. 2014). One of the soils forming factors that influencing the distribution soil properties and water erosion is topography (Amuyou and Kotingo 2015; Khan et al. 2013; Ziadat and Taimeh 2013). As a factor of soil formation, topography has influence on soil chemical and physical properties and also affects the pattern of soil distribution over landscape even when the soils are derived from the same parent material (Lawal et al. 2014).

According to (Musa and Gisilanbe 2017) differences in soil properties due to slope gradient result in detachment, transportation and accumulation of soil materials. Steepness of slope has great effect on soil properties particularly in soil distribution. Aytenew (2015) reported that topography had direct and indirect effect on soil physicochemical properties. Topography gives rise to toposequence of related soils from the same parent materials, about the same age and+occupying under similar climatic conditions but have differences in their characteristics due to change in slope (Osuaku et al. 2014). Slope increases the movement of particles of soil by means of erosion and influences the soil properties considerably (Afshar et al. 2010). As the steepness of the slope increases, water not absorbed by soil increases, but infiltration decreases. As the result of high runoff the accumulation of the clay content decreases with increasing of steepness of slope (Salako et al. 2006). Coarser particles are preferentially accumulated on upper slope positions while finer particles are transported to lower slope positions. As a consequence of this process, different slope gradients may show different soil properties (Wang et al. 2001).

Besides topography, factors enhancing soil loss in Ethiopian highlands are cultivation of steep slopes, the tendency of soils to be affected; incomplete recycling of crop residue, deforestation, overgrazing, and inadequate soil and water conservation measures (Hurni et al. 2010). This indicates that the change in land use and landscape position could able to affect the physicochemical properties of the soil (Getahun et al. 2014). Slope gradient and LU/LC change contribute significantly to crop yield reduction and food insecurity.

There was a rapid soil loss by erosion which is triggered by slope gradient at various parts of the country. Much research has been done on the effects of slope gradient on soil properties in Ethiopia. For example, Asmamaw and Mohammed (2013) study in north eastern Ethiopia showed that high amount of available phosphorus in lower slope positions. Similarly, Selassie et al. (2015) study in the Zikre watershed of northern Ethiopia also reported that the occurrence of variation in soil properties along landscape position. Wubie and Assen (2019) study in the Gumara watershed, Lake Tana basin of North-West Ethiopia reported that the forestland and gentler slopes have lowest bulk density and high total porosity and (Taye et al. 2013) study in Debre-Mewi watershed, Northwestern Ethiopia reported that introduction of soil and water conservation technologies strongly reduced runoff production and soil loss on both land use types and slope gradients. Moreover, Aytenew (2015) study in Dawja watershed of Amhara National Regional State, in northern highlands of Ethiopia also reported that the detrimental effects of slope gradient are higher at moderately steep and strongly sloping areas as compared to sloping and gently sloping areas. However, most studies on the effects of slope gradient on soil properties were concentrated in specific areas, mainly in the Northern highlands of Ethiopia. It is still too limited in Omo Gibe river basin of south central Ethiopia. Slope difference is increasingly recognized as an important cause of soil loss and environmental degradation on all spatial and temporal scales. In addition, it is also one of the factors for the disturbance of local environment by influencing runoff, soil nutrient content and stream flow (Bewket and Solomon 2013).

Even though the study area, Shenkolla watershed, is known to be the productive area of cereal production in the country, the watershed is suffering from soil degradation. Hence, identifying the effect of landscape gradients on the physicochemical properties of soil is fundamental, which have national significance. However, there is no previous study in the area to explain the extent of variations in soil property in relation to landscape position and land use types. Although, the area needs urgent conservation measures, basic information necessary to implement soil resource management and conservation strategies are lacking. Therefore, understanding the effects of landscape position, land use types and their interactive effects on physical and chemical properties of the soil would have a significant advantage on rational planning, and appropriate management of soil of the area. Thus, this study investigated variations in some soil physicochemical properties under different land use types along the slope gradients at Shenkolla watershed, south central Ethiopia.

\section{Materials and methods \\ Description of the study area}

The study area, Shenkolla is found within the Omo Gibe river basin of south central Ethiopia. It is situated approximately $260 \mathrm{~km}$ southwest of Addis Ababa and in a close proximity to the capital city of the Hadiya zone, Hosanna. Shenkolla is geographically located in $7^{\circ} 24^{\prime} 30^{\prime \prime}-$ $7^{\circ} 27^{\prime} 0^{\prime \prime} \mathrm{N}$ Latitude and $37^{\circ} 43^{\prime} 30^{\prime \prime}-37^{\circ} 46^{\prime} 30^{\prime \prime}$ E Longitude (Fig. 1). The altitude in the locality ranges from 2200 and $2830 \mathrm{~m}$ above sea level. 


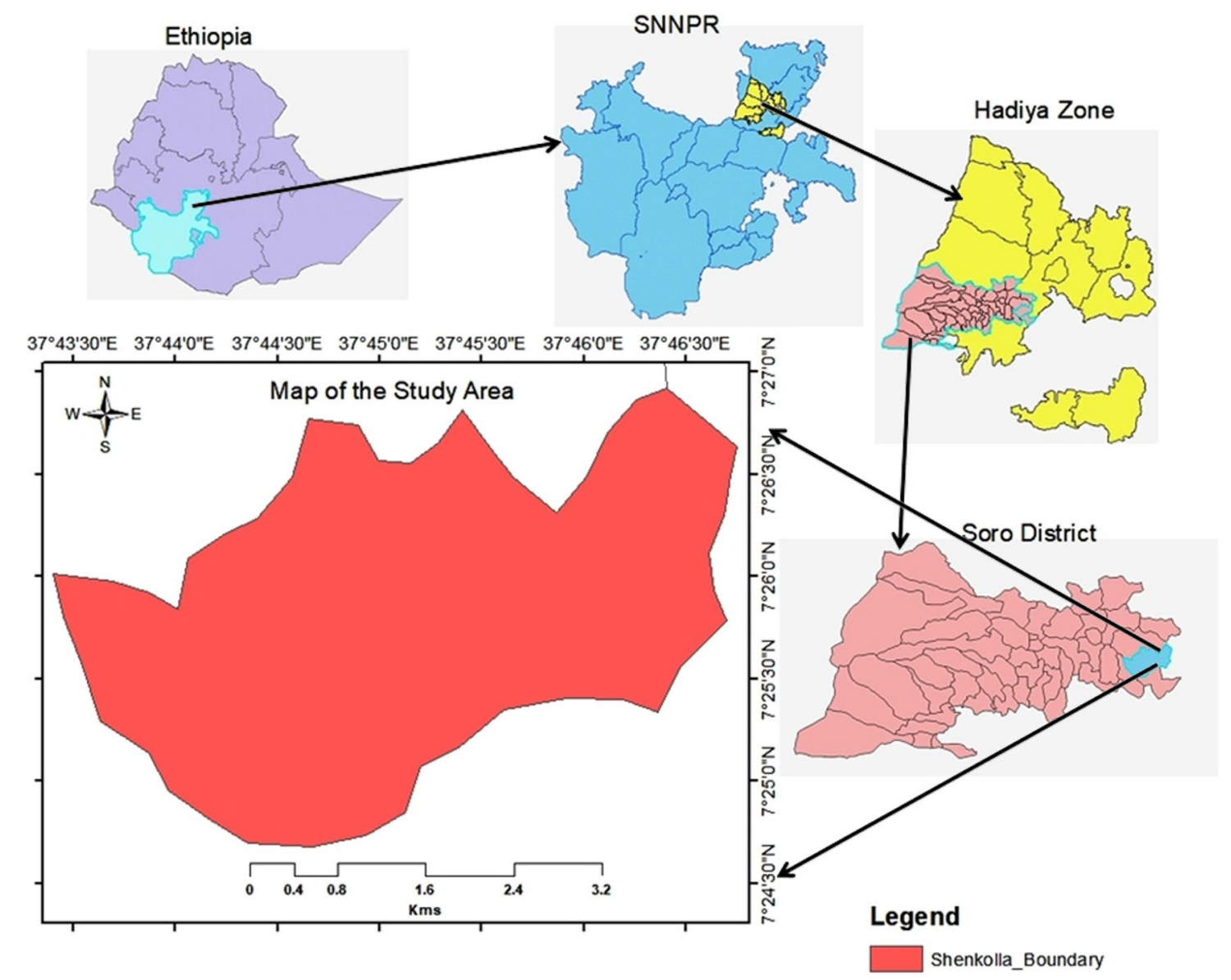

\section{SNNPR}

Fig. 1 Location map of the study area, Shenkolla within the South Central Ethiopia

Soil is a good indicator of the influence of soil parent material and the spatial variability in the degree of weathering, geological and other factors are responsible for soil formation and development (Elias 2016). The dominant soil type of the study area is Nitisols along with Vertisols, Cambisols and Planosols that cover extensive areas of agricultural fields (Elias 2016).

Study area, Shenkolla is generally described by humid climate. The annual long term average precipitation of the watershed is $1107 \mathrm{~mm}$. The watershed exhibits a bimodal rainfall distribution which includes Meher and Belg rainfall. The rainy seasons, locally known as "Meher," extends from June to September and the "Belg," extends from February to May. The long term mean annual temperature of the study area is $17.2^{\circ} \mathrm{C}$ (Fig. 2).

The farming system of the study area is predominantly subsistence farming based on mixed crop-livestock production. Major crops grown in the area include wheat (Triticum aestivum L.), maize (Zea mays L.), barley (Hordeum vulgare L.), sorghum (Sorghum bicolor (L.) Monench) and teff (Eragrostis tef (Zucc.) Trotter). Farm animals provide essential inputs required for crop production such as ploughing and threshing power in the agricultural production system, while crop production supports the livestock by providing crop residues that supplement the feed required by the livestock. After crop harvest, cattle are let to graze on unwanted plants and crop stalks on the croplands.

\section{Soil sampling and analysis}

On the basis of information obtained from the reconnaissance survey, the landscape of the study area was classified in to three landscape positions according to relative slope gradient, which are having upper with dominant slope gradients of $>30 \%$, middle with dominant slope gradient $15-30 \%$ and lower with dominant slope gradient $0-15 \%$ and three land use types forest, grazing land and cultivated land all under upper, middle and lower landscape positions were selected for soil sampling. Since soils are an integral parts of landscape positions that can be influenced differently by geomorphic and hydrologic processes of the area (Brunner 

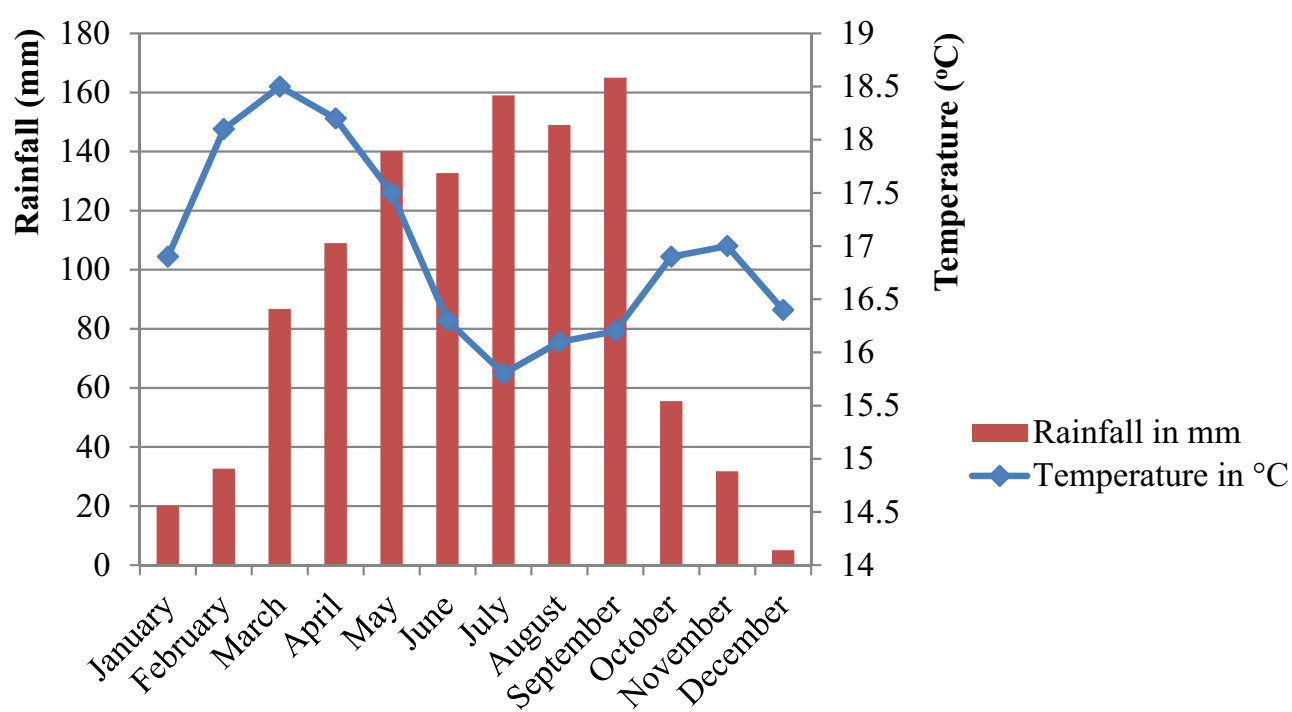

Fig. 2 Mean monthly rainfall and temperature of the study area (Ethiopian Metrological Service 2017)

et al. 2004). Experimental design and arrangements were accomplished using a transect line (Anderson and Ingram 1993). Samples were collected at regular intervals along the transect line. A total of 27 composite soil samples ( 3 treatments (landscape positions) $\times(3$ replications $) \times(3$ land use types) with a soil depth of surface layer $0-20 \mathrm{~cm}$ were collected by taking 9 representative samples from each landscape position. Moreover, undisturbed soil samples were also collected separately using core sampler from each land use type under upper, middle and lower landscape positions for the determination of soil bulk density and water holding capacity. Disturbed soil samples placed in polythene bags and undisturbed soil samples in a steel core sampler were well labeled as described by the Soil Survey Field and Laboratory Method Manual (Burt 2014) and then taken for subsequent laboratory test.

Prior to laboratory analysis, the soil samples were airdried, crushed and passed through $2 \mathrm{~mm}$ sieve. Analyses of the soil samples for field capacity (FC), permanent wilting point (PWP), water holding capacity (WHC), soil aggregate stability and texture were conducted at Ethiopian Water works Construction Design and Supervision Enterprise soil fertility lab following standard laboratory procedures as outlined in (van Reeuwijick 2006). Analyses of the soil samples for bulk density (BD), total porosity (TP), soil $\mathrm{pH}$, organic carbon $(\mathrm{OC})$, total nitrogen, available phosphorus (AP), cation exchange capacity (CEC), exchangeable bases, and some available micro nutrients $(\mathrm{Fe}, \mathrm{Mn}, \mathrm{Zn}$ and $\mathrm{Cu}$ ) were conducted at the soil fertility laboratory of the Agricultural Bureau of Southern Nations Nationalities and People's Region.
The soil particle size distribution was determined by hydrometer method outlined by the simplified procedure of (Day 1965). Soil textural names were determined following the textural triangle of USDA system (Rowell 1994). Bulk density (BD) was estimated from undisturbed soil samples collected using a steel core sampler (Black 1965). Water-holding capacity of the soil was measured using the pressure plate apparatus (Klute 1965). AWC was computed by deducting PWP from FC (Hillel 1980). Water stable aggregate test was carried out by the wet sieving method (Kemper and Rosenau 1986). Soil $\mathrm{pH}\left(\mathrm{H}_{2} \mathrm{O}\right)$ was measured by using a $\mathrm{pH}$ meter in a 1:2.5 soil:water (Peach 1965). The content of soil organic carbon (\%) was decided by the method proposed by Walkley and Black (1934). After laboratory report, SOC content was changed to SOM content using conversion factor of 1.724 adopted from Young (1976) and Tan (1996). The total nitrogen was estimated by Kjeldahl methods (Jackson 1979). Available phosphorus was decided by extraction from the soil using sodium carbonate at $\mathrm{pH}$ equals 8.5 (Olsen et al. 1954). The CEC was determined at soil $\mathrm{pH} 7$ after displacement by using $1 \mathrm{~N}$ Ammonium Acetate method in which it was, thereafter, estimated titrimetrically by distillation of ammonium that was displaced by sodium (Chapman 1965). Exchangeable bases were determined after leaching the soils with ammonium acetate (Thomas 1990). The exchangeable acidity was extracted with $1 \mathrm{M} \mathrm{KCl}$ and it can be determined by the titration method using $0.01 \mathrm{M} \mathrm{NaOH}$ (Sumner and Stewart 1992). Extractable micronutrients (Fe, Mn, Zn and $\mathrm{Cu}$ ) were extracted by diethylene triamine penta acetic acid (DTPA) as described in Sertsu and Bekele (2000). 
The amounts of micronutrients were measured by atomic absorption spectrophotometer at their respective wave lengths.

\section{Statistical analysis}

ANOVA was applied to analyze the difference in mean values of soil parameters among the slope gradients. A Generalized Linear Models (GLMs) analysis was carried out to determine the influence of independent (fixed) factors, on the response variable. Treatment mean comparison was determined using the Least Significant Difference (LSD) at 0.05 level of significance (Gomez and Gomez 1984). Statistical package for SPSS v.16.0 (SPSS, 2007) for windows was used to carry out ANOVA and GLMs.

\section{Results and discussion}

Particle-size distribution

Sand showed highly significant variation along landscape positions and among the land use types $(\mathrm{p}<0.001)$. The mean values of sand content also showed significant difference with interaction effect of landscape position and land use types (LSP*LU) $(P<0.001)$ (Table 1$)$. The soils at upper landscape position had high mean value of sand content $(40.00 \%)$ while the soils at middle landscape was intermediate $(32.67 \%)$ and the lower landscape position had the lowest mean $(27.33 \%)$ with sand content (Table 2). The results showed that sand content increased towards upper landscape position, and this is most probably resulting from the accelerated water erosion which selectively removes fine particles (silt and clay) and leftover accumulation of sand in upper landscape position.

Table 1 ANOVA for particle size distribution and BD as affected by landscape positions and land use types

\begin{tabular}{|c|c|c|c|c|c|c|c|c|c|}
\hline \multirow[t]{2}{*}{ Source of variation } & \multirow[t]{2}{*}{$\mathrm{DgFr}$} & \multicolumn{2}{|l|}{ Sand } & \multicolumn{2}{|l|}{ Silt } & \multicolumn{2}{|l|}{ Clay } & \multicolumn{2}{|l|}{ BD } \\
\hline & & MS & PV & MS & PV & MS & PV & MS & PV \\
\hline LSP & 2 & 364 & 0.001 & 27.815 & 0.044 & 230.481 & 0.003 & 1.000 & 0.008 \\
\hline LU & 2 & 404.333 & 0.000 & 58.926 & 0.000 & 256.926 & 0.001 & 1.000 & 0.008 \\
\hline$L S P * L U$ & 5 & 201.167 & 0.000 & 27.426 & 0.000 & 140.093 & 0.002 & 12.653 & 0.000 \\
\hline Error & 24 & 4.630 & & 0.778 & & 5.778 & & 0.047 & \\
\hline Total & 26 & & & & & & & & \\
\hline
\end{tabular}

MS is the mean square, $\mathrm{PV}$ is the $\mathrm{p}$-value, $\mathrm{DgFr}$ is the degree of freedom

Table 2 Interaction effects of landscape positions and land use types on particle sizes distribution and bulk density (mean \pm SE)

\begin{tabular}{|c|c|c|c|c|c|}
\hline \multirow[t]{2}{*}{ Soil property } & \multirow{2}{*}{$\begin{array}{l}\text { Landscape } \\
\text { Position }\end{array}$} & \multicolumn{3}{|l|}{ Land use types } & \multirow[t]{2}{*}{ Total } \\
\hline & & Cultivated land & Grazing land & Forest & \\
\hline \multirow[t]{4}{*}{ Sand } & Lower & $32.67 \pm 0.333$ & $30.03 \pm 1.856$ & $21.00 \pm 0.577$ & $27.9 \pm 1.795^{\mathrm{a}}$ \\
\hline & Medium & $41.67 \pm 3.383$ & $30.31 \pm 0.577$ & $26 \pm 0.882$ & $32.66 \pm 2.528^{a b c}$ \\
\hline & Upper & $46.00 \pm 0.577$ & $36.00 \pm 0.577$ & $35.25 \pm 0.577$ & $39.08 \pm 2.021^{b c}$ \\
\hline & Total & $40.78 \pm 2.437^{a}$ & $32.11 \pm 1.303 b^{c}$ & $27.78 \pm 2.222^{c}$ & \\
\hline \multirow[t]{4}{*}{ Silt } & Lower & 32. $00 \mathrm{a} \pm 0.577$ & $33.63 \pm 0.577$ & $36.00 \pm 1.155$ & $33.87 \pm 1.167^{a}$ \\
\hline & Medium & $30.70 \pm 0.000$ & $34.38 \pm 0.577$ & $35.00 \pm 1.202$ & $33.36 \pm 0.747^{a b c}$ \\
\hline & Upper & $30.00 \pm 0.000$ & $32.33 \pm 0.333$ & $33.04 \pm 0.333$ & $31.79 \pm 2.638^{c}$ \\
\hline & Total & $30.9 \pm 0.745^{a}$ & $33.00 \pm 0.878^{b}$ & $35.078 \pm 0.645^{c}$ & \\
\hline \multirow[t]{4}{*}{ Clay } & Lower & $35.33 \pm 0.882$ & $36.34 \pm 0.882$ & $44.00 \pm 1.528$ & $38.55 \pm 2.242^{a}$ \\
\hline & Medium & $27.67 \pm 3.180$ & $35.31 b \pm 0.000$ & $39.00 \pm 0.577$ & $33.99 \pm 1.904^{\mathrm{abc}}$ \\
\hline & Upper & $24.00 \pm 0.577$ & $31.67 \pm 0.882$ & $31.71 \pm 0.000$ & $29.12 \pm 1.341^{c}$ \\
\hline & Total & $29.00 \pm 1.929^{a b}$ & $33.78 \pm 0.641^{b c}$ & $39.67 \pm 2.363^{c}$ & \\
\hline \multirow[t]{4}{*}{ Bulk density } & Lower & $1.52 \pm 0.333$ & $1.28 \pm 0.000$ & $1.11 \pm 0.005$ & $1.30 \pm 0.000^{a}$ \\
\hline & Medium & $1.57 \pm 0.025$ & $1.32 \pm 0.092$ & $1.13 \pm 0.005$ & $1.34 \pm 0.167^{a b c}$ \\
\hline & Upper & $1.72 \pm 0.015$ & $1.38 \pm 0.010$ & $1.21 \pm 0.020$ & $1.44 \pm 0.167^{c}$ \\
\hline & Total & $1.60 \pm 0.167^{a b}$ & $1.33 \pm 0.167^{b c}$ & $1.15 \pm 0.000^{c}$ & \\
\hline
\end{tabular}

Means in the same row for land use and in the same column for landscape position followed by the similar letters are not significantly different at $(p=0.05$ ) 
These results are in agreement with the findings of Ayele et al. (2013), who reported that high mean value of sand under soils of upper landscape positions. High mean value of sand (40.78\%) was found on soils under the cultivated land. Grazing land soil had the intermediate value of sand (31.44\%) while the forest land had low sand content $(27.78 \%)$ (Table 2). This result disagrees with the studies by Habtamu et al. (2014) who reported the highest, mean value of bulk density under grazing land as compared to cultivated land. Moreover, Least Significant Difference (LSD) test revealed that lower landscape position showed significantly lower sand content than upper landscape position and forest land had significantly lower sand content than cultivated lands. High sand content in the soil of cultivated and grazing lands might be due to the removal of fine particles by water erosion and leaving coarse fractions in cultivated and grazing lands. These results are in agreement with Tsehaye and Mohammed (2013), who explained that cultivated and grazing lands are extremely susceptible to erosion, because they have less vegetation cover.

Silt showed significant variation along landscape positions $(\mathrm{p}<0.05)$. Silt fraction also showed significant variation among the land use types $(\mathrm{p}<0.001)$. Landscape position and land use types (LSP*LU) had a significant interactive effect $(P<0.001)$ on silt content (Table 1$)$. The soils at upper landscape position had low mean value of silt $(31.22 \%)$ while the lower landscape position had the highest (34.67\%) and the soils at middle landscape had intermediate $(33.56 \%)$ with silt content. The soils of forest land had the high mean value of silt (35.78\%), but the soils of grazing land had intermediate $(33.00 \%)$ and cultivated land had low percentage of silt (30.67\%) (Table 2). Least Significant Difference (LSD) test also revealed that lower landscape position had significantly higher silt content than upper landscape position and cultivated land had significantly lower silt content than grazing and forest lands.

Clay fraction varied significantly along landscape positions $(\mathrm{p}<0.01)$. Clay had showed substantial variation among the land use types $(\mathrm{p}<0.001)$. The results of this study also showed significant variation of clay content with interaction effects of landscape position and land use types $(\mathrm{LSP} * \mathrm{LU})(P<0.01)$ (Table 1$)$. The mean value of clay was comparatively higher as compared to the values of sand and silt in lower landscape positions across all land use types.

The entire area where clay is found along landscape positions was in order: lower landscape (39.33) $>$ middle landscape (33.89) > upper landscape positions (29.22) (Table 2), indicating that clay content increases towards lower landscape. This might be due to the washing away of fine soil particles from steeper landscapes and their deposition at lower landscape gradient. The result also shows that the forest soils had the high mean value of clay (39.67\%) but the crop land soils had the lowest mean value of clay $(29.00 \%)$ and the grazing land soils had intermediate mean value of clay content (33.78\%) (Table 2). Least Significant Difference (LSD) test also revealed that lower landscape position had significantly higher clay content than upper landscape position and cultivated land had significantly lower clay content than forest lands.

\section{Bulk density}

Bulk density had shown substantial variation with landscape positions and land use types $(\mathrm{P}<0.01)$. The result also indicated that bulk density significantly varied with interaction effects of landscape position and land use classes $(\mathrm{LSP} * \mathrm{LU})(P<0.001)$ (Table 1$)$. With regard to distribution of bulk density along landscape position, lower landscape $\left(1.30 \mathrm{~g} / \mathrm{cm}^{3}\right)<$ middle landscape $(1.34 \mathrm{~g} /$ $\left.\mathrm{cm}^{3}\right)<$ upper landscape positions $\left(1.44 \mathrm{~g} / \mathrm{cm}^{3}\right)$ (Table 2), indicating that bulk density decreases towards down landscape position. Least Significant Difference (LSD) test also revealed that upper landscape position had significantly higher bulk density than lower landscape position. Low bulk density of the lower landscape position might be attributable to the high quantity of organic matter and clay content. Similarly, this result is in agreement with the findings of (Safadoust et al. 2015) who reported that low and high bulk density values were observed in lower slope and upper slope, respectively, caused by variation in contents of clay fraction and organic matter. Low bulk density $\left(1.15 \mathrm{~g} / \mathrm{cm}^{3}\right)$ was found in forest soil followed by the soil under grazing land (1.33), while soil under crop land had a high bulk density $\left(1.60 \mathrm{~g} / \mathrm{cm}^{3}\right)$ (Table 2). Higher bulk density of cultivated land is caused by continuous tillage operations, which in turn lower SOC (through rapid mineralization of SOM) and thereby an increase in soil bulk density. Tillage practices in cultivated land contribute for the reduction of soil organic carbon by disaggregating soil structure, thereby exposing organic matter for decomposing agent. It implies that tillage in cultivated land led to compaction of soil which enhanced soil bulk density. High bulk density values in grazing land might be attributed to compaction by livestock and low organic matter content. Least Significant Difference (LSD) test also revealed that upper slopes had significantly higher bulk density than lower landscape position and cultivated land had significantly higher bulk density than grazing and forest lands. This result is similar with the findings of Kakaire et al. (2015), that reported significantly higher bulk density under the soils of upper landscape position and cultivated land. 
Water holding capacity and water stable aggregates

Water holding capacity at FC had shown significant variation with landscape positions, with land use types and with interaction effects of landscape positions and land use types $(\mathrm{LSP} * \mathrm{LU})(\mathrm{P}<0.001)$ (Table 3$)$. Lower landscape position had the highest mean value of water holding capacity at FC (34.56\%) followed by middle landscape positions (29.11\%). Those soils under upper landscape position had the lowest mean values of water holding capacity at FC (23.22\%) (Table 4). Water retention at FC of the soil increased towards lower landscape positions. The higher water retention at FC (34.89\%) was recorded under soils of forest land, while the lower content (23.78\%) was under crop land. Least Significant Difference (LSD) test revealed that upper landscape position had significantly lower water retention capacity at FC than lower and middle landscape positions and cultivated and grazing lands had significantly lower water retention at FC than forest land (Table 4).

Water retention at PWP also influenced significantly with landscape positions $(\mathrm{p}<0.01)$. Water retention at PWP had shown significant difference with land use types $(\mathrm{P}<0.001)$. The result showed that the water retention at PWP substantially varied with interaction effects of landscape position and land use types (LSP*LU) $(P<0.001)$ (Table 3$)$. Lower landscape position had the highest mean value of water retention at PWP (19.22\%) followed by middle landscape positions (15.44\%). Those soils under upper landscape position had the lowest mean values of water retention at PWP (12.33\%). Higher mean value of water retention at PWP (19.89\%) was recorded under soils of forest land, while the lower content (12.67\%) was under the soils of crop land. Least Significant Difference (LSD) test revealed that lower landscape position had significantly higher water holding capacity at PWP than upper landscape position and cultivated and grazing lands had significantly lower water retention capacity at PWP than forest land (Table 4).

Available water content (AWC) significantly varied with landscape position and land use types $(\mathrm{P}<0.01)$.
The results also shown that soil available water content significantly varied with interaction effects of landscape position and land use types ( $\mathrm{LSP} * \mathrm{LU})(\mathrm{P}<0.001)$ (Table 3). Lower landscape position had the highest mean value of available water content (15.11\%) followed by middle landscape positions (13.67\%). Those soils under upper landscape position had the lowest mean value of available water content (10.78\%). This result showed that available water content of the soil increased down landscape positions (Table 4). The higher mean value of soil water content $(14.78 \%)$ was recorded under soils of forest land, while the lower content (11.00\%) under the soils of crop land (Table 4). The mean value of available water content on forest land use was found to be higher as compared to cultivated and grazing land uses. This result agrees with the findings of (Getachew et al. 2012) who reported that soil moisture content showed significant variations between the soils of the different land use types and landscape positions. LSD test revealed that upper landscape position had significantly lower available water content than middle and lower landscape positions and forest land had significantly higher available water content than cultivated and grazing lands (Table 4).

Water stable aggregates (STA) hadn't shown significant variation with landscape position but showed significant variation with land use types $(\mathrm{P}<0.01)$. The results also shown that water stable aggregates significantly varied with interaction effects of landscape position and land use types (LSP*LU) $(\mathrm{P}<0.001)$ (Table 3). Lower landscape position had the highest mean value of water stable aggregates (74.86\%) followed by middle landscape positions (73.67\%). Those soils under upper landscape position had the lowest mean value of water stable aggregates $(72.90 \%)$. This result showed that water stable aggregates of the soil increased down landscape positions (Table 4). Water stable aggregate was the highest $(80.70 \%)$ and intermediate $(72.27 \%)$ in forest and grazing land respectively,

Table 3 ANOVA for FC, PWP AWC and STA as affected by landscape positions and land use types

\begin{tabular}{|c|c|c|c|c|c|c|c|c|c|}
\hline \multirow[t]{2}{*}{ Source of variation } & \multirow[t]{2}{*}{$\mathrm{DgFr}$} & \multicolumn{2}{|l|}{ FC } & \multicolumn{2}{|l|}{ PWP } & \multicolumn{2}{|l|}{ AWC } & \multicolumn{2}{|l|}{ STA } \\
\hline & & MS & PV & MS & PV & MS & PV & MS & PV \\
\hline LSP & 2 & 289.148 & 0.000 & 107.111 & 0.002 & 43.815 & 0.002 & 8.829 & 0.746 \\
\hline LU & 2 & 281.481 & 0.000 & 127.444 & 0.000 & 34.481 & 0.010 & 352.669 & 0.000 \\
\hline$L S P * L U$ & 5 & 138.17 & 0.000 & 61.667 & 0.000 & 24.897 & 0.000 & 78.767 & 0.000 \\
\hline Error & 24 & 0.967 & & 0.97 & & 0.056 & & 1.08 & \\
\hline Total & 26 & & & & & & & & \\
\hline
\end{tabular}


Table 4 Interaction effects of landscape positions and land use types on water retentive capacity and water stable aggregates (mean $\pm \mathrm{SE}$ )

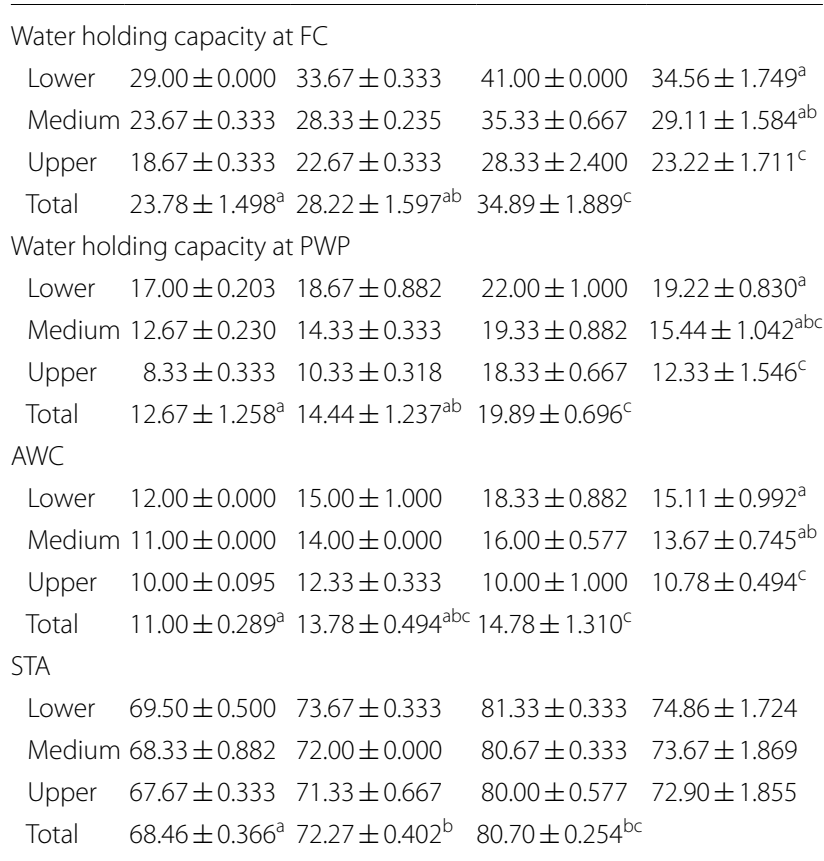

Means in the same row for land use and in the same column for landscape position followed by the similar letters are not significantly different at $(p=0.05)$

showing high amount of organic matter that served as binding agents making the soils stick together (Table 4). However, the lower content of water stable aggregates $(68.46 .00 \%)$ was recorded under the soils of crop land. Agricultural technologies and intensive cultivation make the soil structural aggregation worse under cultivated lands which are indicated by a reduced stable aggregate. This result is in agreement with the findings of Safadoust et al. (2015). LSD test revealed that significantly high available water content was found in forest land as compared to grazing and cultivated lands (Table 4).
$\mathrm{pH}\left(\mathrm{H}_{2} \mathrm{O}\right), \mathrm{SOC}$, total nitrogen, $\mathrm{C} / \mathrm{N}$ ratio and available phosphorus

The results of the study showed significant variation of soil $\mathrm{pH}\left(\mathrm{H}_{2} \mathrm{O}\right)$ with landscape categories $(\mathrm{P}<0.05)$ and across land use types $(\mathrm{P}<0.01)$. Soil $\mathrm{pH}\left(\mathrm{H}_{2} \mathrm{O}\right)$ significantly varied with interaction effects of landscape positions and land use types (LSP*LU) $(\mathrm{P}<0.001)$ (Table 5). The mean value of soil $\mathrm{pH}$ is higher (5.84) in the lower landscape position than in the upper landscape (5.39) (Table 6). This suggests that $\mathrm{pH}$ increases as the slope of landscape decreases. The lowest $\mathrm{pH}$ in soils of upper landscape position might be due to the loss of exchangeable bases caused by wearing away of the surface soil via runoff and erosion. These conditions increase the activity of $\mathrm{H}^{+}$ion in the soil and reduce the soil $\mathrm{pH}$. The result of this study in lines with the finding of Emiru and Gebrekidan (2013), who reported that loss of basic cations by means of runoff generated from severe erosion reduces soil $\mathrm{pH}$ in cultivated land which in turn increases soil acidity. Moreover, this result is in agreement with studies by Alemayehu and Sheleme (2013), who reported that lower $\mathrm{pH}$ values under cultivated land than agroforestry land use types. But, this result disagrees with findings of Kotingo (2015), who gave detail information that a higher $\mathrm{pH}$ values at upper slope position as compared to middle and lower slope positions. Cultivated land had the lowest mean value of $\mathrm{pH}$ (5.35) as compared to forest land (6.03) which had the highest $\mathrm{pH}$ value (Table 6). Low mean value of soil $\mathrm{pH}$ under the cultivated land might be due to depletion and removal of basic cations. This result is not in agreement with the findings of Yimer et al. (2007), who reported high $\mathrm{pH}$ values for cultivated land as compared to other land use types. Similarly, this result disagrees with the findings of Kizilkaya and Dengiz (2010), who reported a significant increase of $\mathrm{pH}$ in soils under cultivated land. Least Significant Difference (LSD) test revealed that $\mathrm{pH}$ value in upper landscape position was significantly higher than lower landscape position and the $\mathrm{pH}$ value of soil in cultivated land was significantly lower than the $\mathrm{pH}$ value of soil in forest land.

Table 5 ANOVA for pH (H2O), SOC, TN, C/N ratio and AP as affected by landscape positions and land use types

\begin{tabular}{|c|c|c|c|c|c|c|c|c|c|c|c|}
\hline \multirow[t]{2}{*}{ Source of variation } & \multirow[t]{2}{*}{$\mathrm{DgFr}$} & \multicolumn{2}{|c|}{$\mathrm{pH}\left(\mathrm{H}_{2} \mathrm{O}\right)$} & \multicolumn{2}{|l|}{ SOC } & \multicolumn{2}{|l|}{$\mathrm{TN}$} & \multicolumn{2}{|l|}{$\mathrm{C} / \mathrm{N}$} & \multicolumn{2}{|l|}{ AP } \\
\hline & & MS & PV & MS & PV & MS & PV & MS & PV & MS & PV \\
\hline LSP & 2 & 0.149 & 0.033 & 0.06 & 0.009 & 0.498 & 0.010 & 2.838 & 0.000 & 2.003 & 0.016 \\
\hline LU & 2 & 1.132 & 0.000 & 0.303 & 0.002 & 0.587 & 0.000 & 11.251 & 0.029 & 53.126 & 0.000 \\
\hline$L S P^{*} \mathrm{LU}$ & 5 & 0.336 & 0.000 & 0.104 & 0.000 & 0.51 & 0.004 & 4.063 & 0.000 & 0.240 & 0.000 \\
\hline Error & 24 & 0.026 & & 0.001 & & 0.112 & & 0.140 & & 0.001 & \\
\hline Total & 26 & & & & & & & & & & \\
\hline
\end{tabular}

MS is the mean square, $\mathrm{PV}$ is the $\mathrm{p}$-value, $\mathrm{DgFr}$ is the degree of freedom 
Table 6 Interaction effects of landscape positions and land use types on soil properties (mean \pm SE)

\begin{tabular}{|c|c|c|c|c|c|}
\hline \multirow[t]{2}{*}{ Soil property } & \multirow{2}{*}{$\begin{array}{l}\text { Landscape } \\
\text { Position }\end{array}$} & \multicolumn{3}{|l|}{ Land use types } & \multirow[t]{2}{*}{ Total } \\
\hline & & Cultivated land & Grazing land & Forest & \\
\hline \multirow[t]{4}{*}{$\mathrm{pH}(\mathrm{H} 2 \mathrm{O})$} & Lower & $5.51 \pm 0.008$ & $5.64 \pm 0.020$ & $6.37 \pm 0.023$ & $5.84 \pm 0.134^{\mathrm{a}}$ \\
\hline & Medium & $5.42 \pm 0.012$ & $5.59 \pm 0.038$ & $6.00 \pm 0.271$ & $5.67 \pm 0.117^{a b c}$ \\
\hline & Upper & $5.32 \pm 0.017$ & $5.32 \pm 0.020$ & $5.92 \pm 0.014$ & $5.39 \pm 0.088 c$ \\
\hline & Total & $5.35 \pm 0.058^{\mathrm{a}}$ & $5.52 \pm 0.051^{\mathrm{abc}}$ & $6.03 \pm 0.123^{c}$ & \\
\hline \multirow[t]{4}{*}{ SOC } & Lower & $0.52 \pm 0.005$ & $2.63 \pm 0.005$ & $3.05 \pm 0.044$ & $2.06 \pm 0.392^{a}$ \\
\hline & Medium & $0.49 \pm 0.008$ & $1.62 \pm 0.021$ & $1.77 \pm 0.008$ & $1.63 \pm 0.041^{a b c}$ \\
\hline & Upper & $1.42 \pm 0.012$ & $0.59 \pm 0.008$ & $1.60 \pm 0.005$ & $0.87 \pm 0.183^{c}$ \\
\hline & Total & $0.81 \pm 0.170^{a}$ & $1.61 \pm 0.888^{b c}$ & $2.14 \pm 0.230^{c}$ & \\
\hline \multirow[t]{4}{*}{ Total nitrogen } & Lower & $0.13 \pm 0.003$ & $0.17 \pm 0.003$ & $0.21 \pm 0.003$ & $0.17 \pm 0.012^{a}$ \\
\hline & Medium & $0.11 \pm 0.003$ & $0.15 \pm 0.003$ & $0.19 \pm 0.006$ & $0.15 \pm 0.011^{\mathrm{a}}$ \\
\hline & Upper & $0.09 \pm 0.006$ & $0.11 \pm 0.005$ & $0.15 \pm 0.008$ & $0.12 \pm .009^{\mathrm{a}}$ \\
\hline & Total & $0.11 \pm 0.005^{\mathrm{a}}$ & $0.14 \pm 0.009^{\mathrm{a}}$ & $0.18 \pm 0.009^{\mathrm{a}}$ & \\
\hline \multirow[t]{4}{*}{$\mathrm{C} / \mathrm{N}$ ratio } & Lower & $12.51 \pm 0.005$ & $13.45 \pm 0.008$ & $15.94 \pm 0.172$ & $13.97 \pm 0.514^{\mathrm{a}}$ \\
\hline & Medium & $10.25 \pm 0.008$ & $11.12 \pm 0.008$ & $11.89 \pm 0.371$ & $11.09 \pm 0.260^{b c}$ \\
\hline & Upper & $10.13 \pm 0.005$ & $10.25 \pm 0.011$ & $11.58 \pm 0.502$ & $10.65 \pm 0.274^{c}$ \\
\hline & Total & $10.96 \pm 0.386^{a}$ & $11.61 \pm 0.478^{\mathrm{ab}}$ & $13.14 \pm 0.726^{c}$ & \\
\hline \multirow[t]{4}{*}{ AP } & Lower & $9.61 \pm 0.005$ & $12.60 \pm 0.005$ & $15.19 \pm 0.005$ & $12.46 \pm 0.806^{\mathrm{a}}$ \\
\hline & Medium & $7.54 \pm 0.007$ & $10.14 \pm 0.005$ & $12.36 \pm 0.005$ & $10.01 \pm 0.696^{b c}$ \\
\hline & Upper & $7.32 \pm 0.005$ & $9.78 \pm 0.005$ & $11.47 \pm 0.005$ & $9.52 \pm 0.602^{c}$ \\
\hline & Total & $8.15 \pm 0.364^{a}$ & $10.84 \pm 0.443^{b c}$ & $13.00 \pm 0.26^{c}$ & \\
\hline
\end{tabular}

Means in the same row for land use and in the same column for landscape position followed by the same letters are not significantly different at ( $\mathrm{p}=0.05$ )

According to Landon (1991) rating, the $\mathrm{pH}$ of the studied soil under upper landscape position was strongly acidic and lower landscape position was moderately acidic while, forest, grazing and cultivated land was found to be slightly acidic, moderately acidic and strongly acidic respectively.

The soil organic carbon (SOC\%) was significantly affected by landscape positions and land use types $(\mathrm{p}<0.01)$. Landscape positions and land use classes $(\mathrm{LSP} * \mathrm{LU})$ also had a significant interaction effect on soil organic carbon $(\mathrm{p}<0.001)$ (Table 5). Lower landscape position had the highest mean value $(2.06 \%)$ of SOC followed by middle landscape positions (1.63\%). Lowest mean value $(0.87 \%)$ of soil organic carbon was found under upper landscape position (Table 6). Soil organic carbon content increases down landscape because lower landscape positions receive high surface soil materials taken from the upper landscape positions. The mean value of SOC was higher in forest soils $(2.14 \%)$, on the contrary, SOC was lower $(0.81 \%)$ under cultivated land of the study area (Table 6). Least Significant Difference (LSD) test indicated that lower landscape position had significantly higher SOC value than upper landscape position and the SOC of soil of cultivated land significantly varied from the soil of forest and grazing land. SOC was rated as very low in upper landscape position and cultivated land, medium in middle landscape position and grazing land and high in lower landscape position and forest land (Hazelton and Murphy 2007). Relatively higher mean value of SOC in forest land use might likely be due to the lower rate of organic carbon turnover as a consequence of lowest possible amount of soil disturbance and continuous addition of $\mathrm{OM}$ in forest land. On the other hand, lower mean value of SOC in cultivated land is due to high oxidation of organic matter and total removal of crop residues. Similar result was reported by Worku et al. (2014) who conducted research in Ameleke micro-watershed.

Total nitrogen had shown significant variation among the landscape positions $(\mathrm{p}<0.01)$ and land uses types $(\mathrm{p}<0.001)$. Landscape positions and land use types (LSP*LU) had a significant interaction influence on total nitrogen $(\mathrm{p}<0.01)$ (Table 5). Lower landscape position had the highest mean (0.17) value of total nitrogen content followed by middle landscape positions (0.15). Those soils under upper landscape position had the lowest mean $(0.12 \%)$ value of total nitrogen (Table 6$)$. High total nitrogen deposition at lower slope position was connected to the displacing of total nitrogen from upper slope positions. Higher mean value of total nitrogen $(0.18 \%)$ was recorded in forest land use followed by grazing land $(0.14 \%)$. Lower mean of total nitrogen $(0.11 \%)$ 
was recorded on cultivated land use (Table 6). The low total nitrogen content on cultivated land might be due to a regular harvesting in which case the crops continuously remove the nutrients from the soil. This result agrees with Alemayehu and Sheleme (2013), who reported that total nitrogen under forest land was higher than cultivated and grazing lands. Similar study conducted by Yimer et al. (2008) found that higher total nitrogen in pasturelands than cultivated lands. Least Significant Difference (LSD) revealed that the total nitrogen value of soils under all landscape positions and all land use types hadn't showed significant difference. Total nitrogen content of the soils were rated as low (deficient) under upper landscape, middle landscape, cultivated and grazing land while, medium (sufficient) within lower landscape positions and forest land (Hazelton and Murphy 2007). Moreover, noticeable losses of total nitrogen in the intensively cultivated lands might be attributed to fast mineralization of SOM following cultivation and inadequate supply of organic and inorganic fertilizers (Emiru and Gebrekidan 2013). Land preparation in cultivated land increases soil air, and improves decomposition of SOM, facilitating the fast degradation and mineralization of the available organic matter by means of that reducing soil organic carbon and nitrogen.

The results of ANOVA indicted that the $\mathrm{C} / \mathrm{N}$ ratio had shown a significant difference with landscape position $(\mathrm{P}<0.001)$. Carbon to nitrogen $(\mathrm{C} / \mathrm{N})$ ratio also varied significantly with land use types $(\mathrm{P}<0.05)$. Landscape position and land use types (LSP*LU) had a significant interactive effect on $\mathrm{C} / \mathrm{N}$ ratio $(\mathrm{p}<0.001)$ (Table 5). The mean values of $\mathrm{C} / \mathrm{N}$ ratio under soils of upper landscape position $(10.65)<$ middle landscape position $(11.09)<$ lower landscape position (13.97) (Table 6). The results indicated that as slope of landscape increases, $\mathrm{C} / \mathrm{N}$ ratio of the soils under all land use types decreases. Low mean value of $\mathrm{C} / \mathrm{N}$ ratio (10.96) was recorded on cultivated land. Higher mean value of $\mathrm{C} / \mathrm{N}$ ratio (13.14) was recorded on forest land use type followed by grazing land (11.61) (Table 6). LSD test also revealed that upper and middle landscape positions had significantly lower $\mathrm{C} / \mathrm{N}$ ratio than lower landscape position and forest land had significantly higher $\mathrm{C} / \mathrm{N}$ ratio than cultivated and grazing land.

The result indicates that available phosphorus varied substantially with landscape positions $(\mathrm{p}<0.05)$, land use types $(\mathrm{P}<0.001)$ and landscape position and land use types $(\mathrm{LSP} * \mathrm{LU})$ had an influential interaction effect on available phosphorus $(\mathrm{p}<0.001)$ (Table 5$)$. High mean value $(12.46 \mathrm{ppm})$ of available phosphorus was found in lower landscape position followed by middle landscape positions (10.01 ppm). Those soils under upper landscape position had the lowest mean value (9.52 ppm) of available phosphorus (Table 6). This is because of the removal of available phosphorus from higher slope gradient. In similar way, Asmamaw and Mohammed (2013) and Wolde et al. (2007) reported that high amount of available phosphorus was recorded in lower slope positions. This result disagrees with the findings of Tellen and Yerima (2018), who reported that at high altitude, the soils under farmland use systems had the highest mean value of soil available phosphorus concentrations. Higher mean value of available phosphorus $(13.00 \mathrm{ppm})$ was found in forest land followed by grazing land $(10.01 \mathrm{ppm})$. Lower mean value of available phosphorus (9.52 $\mathrm{ppm}$ ) was recorded on cultivated land use types (Table 6). This result is in agreement with findings of (Yimer et al. 2008) who reported that higher available phosphorus in natural forest soils than crop and grazing land. On the other hand, this result contradicts with the findings of Awdenegest et al. (2013), who reported that available phosphorus showed no significant difference between the soils under all the land use/land cover systems. LSD test also indicated that lower landscape position had significantly higher available phosphorus than middle and upper landscape positions and cultivated land had significantly lower available phosphorus than grazing and forest lands. Available phosphorus content of the soils was rated as medium under forest, grazing land, lower and middle landscape positions while rated as low under cultivated land and upper landscape position (Hazelton and Murphy 2007). The low available phosphorus content on cultivated land might be due to phosphorus fixation occurred as the result of drain away of base forming cations and subsequent development of acidity. High organic matter content in forest soils contributed to the release of organic phosphorus. This is the reason why forest had relatively higher available phosphorus mean values as compared to grazing and cultivated land soils.

\section{Cation exchange capacity and exchangeable bases}

The results indicated that concentrations of soil cation exchange capacity varied significantly with landscape positions and land use types $(\mathrm{p}<0.001)$. Landscape positions and land use types (LSP * LU) showed a significant interactive influence on cation exchange capacity $(\mathrm{p}<0.001)$ (Table 7). Lower landscape position had the highest CEC $(37.56 \mathrm{cmol}(+) / \mathrm{kg})$, followed by middle $(31.56 \mathrm{cmol}(+) / \mathrm{kg})$ and upper landscapes $(24.78 \mathrm{cmol}$ $(+) / \mathrm{kg})($ Table 8$)$. High clay and organic matter contents in lower landscapes contributed to the high amount of CEC. Similarly, Selassie et al. (2015) reported that the occurrence of variation in soil properties along landscape position. Higher mean value of cation exchange capacity $(36.67 \mathrm{cmol}(+) / \mathrm{kg}$ soil) was found on forest land followed by grazing land $(32.33 \mathrm{cmol}(+) / \mathrm{kg}$ soil). Lower 
Table 7 ANOVA of CEC and exchangeable bases as affected by landscape positions and land use types

\begin{tabular}{|c|c|c|c|c|c|c|c|c|c|c|c|}
\hline \multirow[t]{2}{*}{ Source of variation } & \multirow[t]{2}{*}{$\mathrm{DgFr}$} & \multicolumn{2}{|l|}{ CEC } & \multicolumn{2}{|c|}{ ExcNa } & \multicolumn{2}{|l|}{ Exc K } & \multicolumn{2}{|l|}{ ExcCa } & \multicolumn{2}{|c|}{ Exc Mg } \\
\hline & & MS & PV & MS & PV & MS & PV & MS & PV & MS & PV \\
\hline LSP & 2 & 367.815 & 0.000 & 0.002 & 0.034 & 11.444 & 0.000 & 66.704 & 0.000 & 30.259 & \\
\hline LU & 2 & 3319.37 & 0.001 & 0.019 & 0.000 & 5.444 & 0.013 & 44.481 & 0.003 & 46.704 & 0.000 \\
\hline$L S P * L U$ & 5 & 86.127 & 0.000 & 0.005 & 0.000 & 1.57 & 0.004 & 12.751 & 0.000 & 4.186 & 0.005 \\
\hline Error & 24 & 0.245 & & 0.002 & & 0.022 & & 0.043 & & 0.001 & \\
\hline Total & 26 & & & & & & & & & & \\
\hline
\end{tabular}

MS is the mean square, $\mathrm{PV}$ is $\mathrm{p}$-value, $\mathrm{DgFr}$ is the degree of freedom

Table 8 Interaction effects of landscape positions and land use types on CEC and exchangeable bases (mean \pm SE)

\begin{tabular}{|c|c|c|c|c|c|}
\hline \multirow[t]{2}{*}{ Soil property } & \multirow[t]{2}{*}{ Landscape position } & \multicolumn{3}{|l|}{ Land use types } & \multirow[t]{2}{*}{ Total } \\
\hline & & Cultivated land & Grazing land & Forest & \\
\hline \multirow[t]{4}{*}{ CEC } & Lower & $31.33 \pm 0.333$ & $38.67 \pm 0.202$ & $42.67 \pm 0.333$ & $37.56 \pm 1.668^{b}$ \\
\hline & Medium & $24.67 \pm 0.333$ & $33.33 \pm 0.352$ & $36.67 \pm 0.333$ & $31.56 \pm 1.796^{b c}$ \\
\hline & Upper & $18.67 \pm 0.333$ & $25.00 \pm 0.577$ & $30.67 \pm 0.333$ & $24.78 \pm 1.746^{c}$ \\
\hline & Total & $24.89 \pm 1.837^{\mathrm{a}}$ & $32.33 \pm 2.000^{b c}$ & $36.67 \pm 1.740^{c}$ & \\
\hline \multirow[t]{4}{*}{ Ex Ca } & Lower & $13.67 \pm 0.115$ & $16.00 \pm 0.000$ & $17.33 \pm 0.115$ & $15.67 \pm 0.553^{\mathrm{a}}$ \\
\hline & Medium & $10.33 \pm 0.145$ & $13.00 \pm 0.000$ & $15.33 \pm 0.333$ & $12.89 \pm 0.735^{b}$ \\
\hline & Upper & $8.00 \pm 0.115$ & $12.40 \pm 0.115$ & $12,67 \pm 0.882$ & $10.22 \pm 0.722^{c}$ \\
\hline & Total & $10.67 \pm 0.833^{\mathrm{ab}}$ & $13.80 \pm 0.000^{b c}$ & $15.11 \pm 0.735^{c}$ & \\
\hline \multirow[t]{4}{*}{ ExMg } & Lower & $6.00 \pm 0.006$ & $10.00 \pm 0.014$ & $10.33 \pm 0.015$ & $8.78 \pm 0.703^{a b}$ \\
\hline & Medium & $5.00 \pm 0.008$ & $6.00 \pm 0.001$ & $10.00 \pm 0.020$ & $7.00 \pm 0.764^{\mathrm{ab}}$ \\
\hline & Upper & $3.00 \pm 0.011$ & $5.00 \pm 0.008$ & $7.33 \pm 0.012$ & $5.11 \pm 0.633^{c}$ \\
\hline & Total & $4.67 \pm 0.441^{\mathrm{a}}$ & $7.00 \pm 0.764^{b}$ & $9.22 \pm 0.494^{c}$ & \\
\hline \multirow[t]{4}{*}{ ExK } & Lower & $4.00 \pm 0.020$ & $4.00 \pm 0.020$ & $5.67 \pm 0.230$ & $4.56 \pm 0.294^{\mathrm{a}}$ \\
\hline & Medium & $2.33 \pm 0.333$ & $3.00 \pm 0.011$ & $4.00 \pm 0.041$ & $3.11 \pm 0.261^{b c}$ \\
\hline & Upper & $2.00 \pm 0.014$ & $2.00 \pm 0.034$ & $3.00 \pm 0.087$ & $2.33 \pm 0.167^{c}$ \\
\hline & Total & $2.78 \pm 0.324^{\mathrm{ab}}$ & $3.00 \pm 0.289^{\mathrm{ab}}$ & $4.22 \pm 0.401^{c}$ & \\
\hline \multirow[t]{4}{*}{ Ex Na } & Lower & $0.13 \pm 0.012$ & $0.14 \pm 0.006$ & $0.22 \pm 0.005$ & $0.16 \pm .014^{\mathrm{a}}$ \\
\hline & Medium & $0.12 \pm 0.008$ & $0.13 \pm 0.005$ & $0.21 \pm 0.005$ & $0.15 \pm .014^{\mathrm{a}}$ \\
\hline & Upper & $0.10 \pm 0.006$ & $0.12 \pm 0.005$ & $0.18 \pm 0.003$ & $0.13 \pm .012^{\mathrm{a}}$ \\
\hline & Total & $0.12 \pm 0.006^{\mathrm{ab}}$ & $0.13 \pm 0.004^{\mathrm{ab}}$ & $0.20 \pm 0.005^{c}$ & \\
\hline
\end{tabular}

Means in the same row for land use and in the same column for landscape position followed by the similar letters are not significantly different at ( $p=0.05$ )

mean value of cation exchange capacity $(24.89 \mathrm{cmol}(+) /$ $\mathrm{kg}$ soil) was found in cultivated land (Table 8 ). This result disagrees with the findings of Tellen and Yerima (2018), who reported that CEC did not show a clear picture of the variation under soils of different land use/land cover systems. LSD test indicated that upper landscape position had significantly lower CEC than middle and lower landscape positions and cultivated land had substantially lower CEC than grazing and forest lands. CEC content of the soils were rated as medium under upper landscape position and cultivated land, while, high under lower landscape positions, middle landscape position, forest and grazing lands (Hazelton and Murphy 2007).
ANOVA indicated that concentrations of exchangeable bases $(\mathrm{Ca}, \mathrm{Mg}, \mathrm{Na}$, and $\mathrm{K})$ were significantly $(p<0.001)$, $(p<0.01),(p<0.001)$ and $(p<0.05)$ affected by landscape positions respectively. Exchangeable bases $(\mathrm{Ca}, \mathrm{Mg}, \mathrm{Na}$, and K) were significantly $(p<0.01),(p<0.001),(p<0.001)$ and $(p<0.05)$ affected by land use types respectively. Moreover, exchangeable bases $(\mathrm{Ca}, \mathrm{Mg}, \mathrm{Na}$, and $\mathrm{K})$ were significantly $(p<0.001)$ affected by interaction effects of landscape positions and land use types (LSP * LU) (Table 7). Highest mean values of exchangeable bases $(\mathrm{Ca}, \mathrm{Mg}, \mathrm{Na}$, and $\mathrm{K})$ were recorded in lower landscape positions and the lowest values were in upper landscapes (Table 8). LSD test also indicated that upper landscape 
position had substantially lower exchangeable cations (Ca, $\mathrm{Mg}$ and $\mathrm{K}$ ) than lower landscape position. However, LSD test revealed that exchangeable Na hadn't showed significant variation among the landscape positions. High content of exchangeable bases in lower landscape position might be due to the washing down of cations by erosion from the upper slope and deposited in lower landscapes. This result is supported by previous findings of Tadele et al. (2013) and Wolde et al. (2007), who reported that an increasing tendency of the content of exchangeable bases, as the slope of landscape decreases, which could be the result of lower erosion and higher accumulation at lower landscape position. Calcium was a distinguished dominant exchangeable base among landscape positions and land use types in the following sequence of $\mathrm{Ca}>\mathrm{Mg}>\mathrm{K}>\mathrm{Na}$, however, the concentration of sodium had the smallest component on the exchange complex (Table 8). Furthermore, in association with landscape position, the content of exchangeable bases $(\mathrm{Ca}, \mathrm{Mg}, \mathrm{K}$, and $\mathrm{Na}$ ) took the way in which lower landscape $>$ middle landscape $>$ upper landscape. High mean values of exchangeable bases $(\mathrm{Ca}, \mathrm{Mg}$, $\mathrm{Na}$, and $\mathrm{K}$ ) were recorded in forest land and low values were in cultivated lands (Table 8). This result confirms the findings of Yimer et al. (2008), who reported that the concentration of soil exchangeable $\mathrm{Na}^{+}$was lower in cropland than in the grazing and native forest. LSD test also indicated that significantly lower exchangeable cations $\mathrm{Ca}, \mathrm{Mg}, \mathrm{K}$, and $\mathrm{Na}$ ) were found in cultivated land than forest lands. This is because deforestation, limited recycling of crop residue and wearing away of soil by erosion caused reduction of exchangeable bases on cultivated land (Lechisa et al. 2014).

\section{Micronutrients}

Landscape positions significantly affected micronutrients $(\mathrm{Mn}, \mathrm{Zn}$ and $\mathrm{Cu})(\mathrm{p}<0.001)$ and $\mathrm{Fe}(\mathrm{p}<0.05)$. The results also showed that soil micronutrients ( $\mathrm{Fe}, \mathrm{Mn}$, and $\mathrm{Zn}$ ) varied significantly $(\mathrm{P}<0.001)$, while copper differed significantly $(\mathrm{P}<0.01)$ with land use types. The combination of landscape position and land use types (LSP*LU) showed a significant interaction effect on micronutrients $(\mathrm{p}<0.001)$ (Table 9). Lower landscapes had the highest concentration of micronutrients, followed by middle and upper landscapes (Table 10). High micronutrient values at lower landscapes might be attributed to higher organic matter contents. Higher mean values of micronutrients $(\mathrm{Fe}, \mathrm{Mn}, \mathrm{Zn}$ and $\mathrm{Cu}$ ) were recorded on forest land followed by grazing land. Lower mean values of micronutrients were found on cultivated land (Table 10). The LSD test also revealed that upper landscape position had significantly lower micronutrients $(\mathrm{Fe}, \mathrm{Mn}, \mathrm{Zn}$ and $\mathrm{Cu}$ ) than lower landscape position and cultivated land had significantly lower micronutrients $(\mathrm{Fe}, \mathrm{Mn}, \mathrm{Zn}$, and $\mathrm{Cu}$ ) than the forest and grazing land. SOM may promote the availability of such nutrients by supplying soluble organic acids that interfere with their fixation (Blair et al. 1991). This result was also supported by the findings of Aluko and Fagbenro (2000) who stated that micronutrients increased with the increase in SOM and total nitrogen.

Generally, the results of this study indicated that at upper slopes, soils under forest, grazing land and cultivated land showed low potential plant nutrients. Our results seem to indicate that severe erosion at upper slope position negatively affected soil quality as compared to middle and lower slope positions. The physical features of the land in the study area contributed to soil erosion. Land with a steep slope facilitated the process of rainwater flow rate and washing away of nutrients in the area, particularly due to the faster movement of the water toward lower slope. Severe soil erosion played a significant role in removing soil nutrients from upper landscape position to lower landscape position is a major environmental problem. If there are no efforts to check the potential danger of erosion, it will have implications on increasing soil loss in particular and environmental degradation in general. Therefore, proper management of soil in different landscape is important to ensure environmental sustainability, since soils are in the front line of environmental change. Moreover, Landscape

Table 9 ANOVA for micronutrients as influenced by landscape positions and land use types

\begin{tabular}{|c|c|c|c|c|c|c|c|c|c|}
\hline \multirow[t]{2}{*}{ Source of variation } & \multirow[t]{2}{*}{$\mathrm{DgFr}$} & \multicolumn{2}{|l|}{$\mathrm{Fe}$} & \multicolumn{2}{|l|}{$\mathrm{Mn}$} & \multicolumn{2}{|l|}{$\mathrm{Zn}$} & \multicolumn{2}{|l|}{$\mathrm{Cu}$} \\
\hline & & MS & PV & MS & PV & MS & PV & MS & PV \\
\hline LSP & 2 & 8575.148 & 0.031 & $20,967.37$ & 0.003 & 56.259 & 0.005 & 1.037 & 0.008 \\
\hline$L U$ & 2 & $23,814.04$ & 0.000 & $29,130.48$ & 0.000 & 97.926 & 0.000 & 1.037 & 0.008 \\
\hline$L S P * L U$ & 5 & 8255.898 & 0.000 & $13,135.51$ & 0.000 & 39.12 & 0.000 & 0.704 & 0.000 \\
\hline Error & 24 & 26.551 & & 7.57 & & 26.551 & & 7.57 & \\
\hline Total & 26 & & & & & & & & \\
\hline
\end{tabular}

MS is mean square, $\mathrm{PV}$ is $\mathrm{p}$-value, $\mathrm{DgFr}$ is the degree of freedom 
Table 10 Interaction effects of landscape positions and land use types on micronutrients (mean $\pm \mathrm{SE}$ )

\begin{tabular}{|c|c|c|c|c|c|}
\hline \multirow[t]{2}{*}{ Soil property } & \multirow{2}{*}{$\begin{array}{l}\text { Landscape } \\
\text { Position }\end{array}$} & \multicolumn{3}{|l|}{ Land use types } & \multirow[t]{2}{*}{ Total } \\
\hline & & Cultivated land & Grazing land & Forest & \\
\hline \multirow[t]{4}{*}{$\mathrm{Fe}$} & Lower & $194.33 \pm 8.686$ & $225.00 \pm 0.000$ & $292.67 \pm 13.860$ & $237.33 \pm 15.273^{a b}$ \\
\hline & Medium & $175.33 \pm 0.882$ & $221.67 \pm 0.333$ & $266.67 \pm 0.333$ & $221.22 \pm 13.186^{a b c}$ \\
\hline & Upper & $116.33 \pm 9.871$ & $181.67 \pm 1.155$ & $235.00 \pm 0.577$ & $177.67 \pm 17.393^{b c}$ \\
\hline & Total & $162.00 \pm 12.342^{a}$ & $209.44 \pm 6.962^{b}$ & $264.78 \pm 9.249^{c}$ & \\
\hline \multirow[t]{4}{*}{$\mathrm{Mn}$} & Lower & $157.67 \pm 0.333$ & $260.33 \pm 0.333$ & $270.33 \pm 22.303$ & $229.44 \pm 19.120^{a b}$ \\
\hline & Medium & $113.33 \pm 0.333$ & $188.12 \pm 1.076$ & $226.33 \pm 0.882$ & $175.89 \pm 16.594^{a b c}$ \\
\hline & Upper & $84.67 \pm 0.333$ & $117.67 \pm 2.603$ & $197.00 \pm 3.055$ & $133.11 \pm 16.708^{b c}$ \\
\hline & Total & $118.56 \pm 10.619^{a}$ & $188.67 \pm 20.609^{b}$ & $231.22 \pm 12.483^{c}$ & \\
\hline \multirow[t]{4}{*}{$\mathrm{Zn}$} & Lower & $5.00 \pm 0.000$ & $6.67 \pm 0.333$ & $12.00 \pm 0.000$ & $7.89 \pm 1.060^{\mathrm{ab}}$ \\
\hline & Medium & $2.00 \pm 0.000$ & $5.00 \pm 0.000$ & $9.00 \pm 0.000$ & $5.33 \pm 1.014^{\mathrm{abc}}$ \\
\hline & Upper & $0.67 \pm 0.458$ & $2.00 \pm 0.000$ & $6.00 \pm 0.000$ & $2.89 \pm 0.807^{b c}$ \\
\hline & Total & $2.56 \pm 0.648^{\mathrm{a}}$ & $4.56 \pm 0.689^{b}$ & $9.00 \pm 0.866^{c}$ & \\
\hline \multirow[t]{4}{*}{$\mathrm{Cu}$} & Lower & $0.46 \pm 0.011$ & $0.57 \pm 0.028$ & $0.75 \pm 0.017$ & $0.67 \pm 0.167^{\mathrm{ab}}$ \\
\hline & Medium & $0.34 \pm 0.021$ & $0.44 \pm 0.049$ & $0.60 \pm 0.005$ & $0.44 \pm 0.176^{\mathrm{abc}}$ \\
\hline & Upper & $0.22 \pm 0.012$ & $0.29 \pm 0.014$ & $0.45 \pm 0.024$ & $0.32 \pm 0.000 b^{c}$ \\
\hline & Total & $0.34 \pm 0.010^{\mathrm{a}}$ & $0.44 \pm 0.176^{b}$ & $0.67 \pm 0.167^{c}$ & \\
\hline
\end{tabular}

Means in the same row for land use and in the same column for landscape position followed by similar letters are not significantly different at ( $\mathrm{p}=0.05$ )

management could play a significant role in the restoring productivity to soils that have previously experienced productivity losses and protection of the rich variety of biological and physical resources that are available in the environment. Importantly, land restoration activities with particular attention to upper landscape position help to increase soil fertility, thus enhancing crop production and reducing food insecurity. Finally, the result of this study could be used as input to show a clear pathway to ensure productivity of land, while providing opportunities to support achievement of the sustainable development.

\section{Conclusion}

The results of the study indicated that landscape positions, land use types and interaction effects of landscape positions and land use types (LSP*LU) significantly affected soil texture (sand, silt and clay), bulk density, water holding capacity at FC and PWP, water stable aggregate, soil pH, SOC, TN, AP, CEC, EB (Ca, Mg, Na and $\mathrm{K}$ ) and micronutrients. Lower landscape position and forest land had the highest mean values of soil quality indicators (organic carbon, total nitrogen, $\mathrm{C} / \mathrm{N}$ ratio, available phosphorus, CEC, exchangeable bases and available micronutrients), while upper landscape position and cultivated land had the lowest mean values. This shows that the soil with best quality was found in lower landscape position and forest land, while less quality of soil was found in upper landscape position and cultivated land. Therefore, immediate application of appropriate sustainable land management practices focused on soil conservation that lead to improved biodiversity, restoration of degraded lands, minimizing soil erosion and increasing productivity are very crucial in upper landscape position and cultivated land to increase the regulation and provision of ecosystem services.

The scope of this research was limited to only evaluating the effects of landscape positions and land use types on soil physicochemical properties with a soil depth of surface layer $0-20 \mathrm{~cm}$. Thus, further research should be carried out in detail on identifying the combined effects of landscape positions, land management practices and different soil depths.

\section{Recommendations}

It is recommended that encouraging the integration of experts specialized with different subjects or skills are required to develop a plan for sustainable resource management and restoration of the degraded landscapes of the area to ensure its functions for the next generations.

\section{Abbreviations}

ANOVA: Analysis of variance; AP: Available phosphorus; AWC: Available water content; BD: Bulk density; CEC: Cation exchange capacity; C/N: Carbon to nitrogen ratio; FC: Field capacity; LSD: Least Significant Difference; LSP: Landscape position; LU: Land use (\%); PWP: Permanent wilting point; SOC: Soil organic carbon; SNNPR: Southern Nations Nationalities and People's Region; STA: Stable aggregates; TN: Total nitrogen.

\section{Acknowledgements}

The authors would like to thank the editor and anonymous reviewers for their comments, which greatly improved the quality of this manuscript. 


\section{Authors' contributions}

BB carried out designing the research idea, method design, field data collection, data analysis and interpretation, prepare draft of the manuscript, and structuring the report; EE and GA supervised the inception, design and edited the manuscript. All authors read and approved the final manuscript.

\section{Authors' information}

Belayneh Bufebo is a Ph.D. candidate in Environmental Science at Addis Ababa University and lecturer at department of Natural Resource Management in Wachemo University. He has given different courses such as Introduction to Environmental Science, Introductory Soils, Land Degradation and Rehabilitation, Environmental Impact Assessment and also published more than 5 articles in the internationally peer reviewed journals.

Eyasu Elias is a Ph.D. working in the area of Soil Science and environment having 20 years of post-Ph.D. research, teaching and development work. Currently, he holds associate Professor's position with College of Natural and Computational Science of Addis Ababa University. Over the past years, he has been working on soil survey, characterization and mapping work with scientists from the Wageningen University and Research Centre and the International Soil Reference and Information Centre (ISRIC), the Netherlands. Some of his work has recently been published in a book entitled, "Soils of the Ethiopian Highlands: Geomorphology and Properties" —ISBN: 978-99944-9526-9. In addition, he published a number of peer reviewed journal articles and book chapters previously.

Getachew Agegnehu (Ph.D.) is a researcher in Ethiopian Institute of Agricultural Research. He has published several peer reviewed papers in the internationally peer reviewed journals.

\section{Funding}

The research was funded by Addis Ababa University and Wachemo University.

\section{Availability of data and materials}

I declare that the data and materials presented in this manuscript can be made publically available by Springer Open as per the editorial policy.

\section{Ethics approval and consent to participate}

Not applicable to this manuscript submission.

\section{Consent for publication}

The manuscript does not contain any data or information from any person or individual apart from their own field investigation. All data and information are generated and synthesized by the authors themselves.

\section{Competing interests}

The authors declare that they have no competing interests.

\section{Author details}

${ }^{1}$ Department of Natural Resource Management, Wachemo University, P.O. Box 667, Hosanna, Ethiopia. ${ }^{2}$ Center for Environmental Science, College of Natural and Computational Sciences, Addis Ababa University, Addis Ababa, Ethiopia. ${ }^{3}$ Ethiopian Institute of Agricultural Research, Addis Ababa, Ethiopia.

Received: 11 December 2020 Accepted: 2 February 2021

Published online: 08 February 2021

\section{References}

Afshar FA, Ayoubi S, Jalalain A (2010) Soil redistribution rate and its relationship with soil organic carbon and total nitrogen using 137Cs technique in a cultivated complex hillslope in western Iran. J Environ Radioact 101:606-614

Alemayehu K, Sheleme B (2013) Effects of different land use systems on selected soil properties in South Ethiopia. J Soil Sci Environ Manag 5:100-107

Aluko AP, Fagbenro JA (2000) The role of tree species and land use systems in organic matter and nutrient availability in degraded Ultisol of Onne, Southeastern Nigeria. In: Proceedings of the 26th annual conference soil science society of Nigeria, vol 3, pp 89-292
Anderson JM, Ingram JSI (eds) (1993) Tropical soil biology and fertility: a handbook of methods, 2nd edn. Oxford University Press, Oxford, p 240

Asmamaw LB, Mohammed AA (2013) Effects of slope gradient and changes in land use/cover on selected soil physico-biochemical properties of the Gerado catchment, north-eastern Ethiopia. Int J Environ Stud 70:111-125

Awdenegest M, Melku D, Fantaw Y (2013) Land use effects on soil quality indicators: a case study of Abo-Wonsho southern Ethiopia. Appl Environ Soil Sci. https://doi.org/10.1155/2013/784989

Ayele T, Beyene S, Esayas A (2013) Changes in land use on soil physicochemical properties: the case of smallholders fruit-based land use systems in Arba Minch, southern Ethiopia. Int J Curr Res 5(10):3203-3210

Aytenew M (2015) Effect of slope gradient on selected soil physicochemical properties of Dawja Watershed in Enebse Sar Midir District, Amhara National Regional State. Am J Sci Ind Res 6(4):74-81

Bewket W, Solomon A (2013) Land-use and land-cover change and its environmental implications in a tropical highland watershed, Ethiopia. Int J Environ Stud 70(1):126-139

Black CA (1965) Methods of soil analysis. Part I. American Society of Agronomy, Madison, p 1572

Blair GJ, Chinoim N, Lefroy RDB, Anderson GC, Croccker GJ (1991) A soil sulfur test for pastures and crops. Aust J Soil Resour 29:619-626

Brunner AC, Park SJ, Ruecker GR, Dikau R, Vlek PLC (2004) Catenary soil development influencing erosion susceptibility along hillslope in Uganda. CATENA 58(1):1-22

Burt R (2014) Soil survey staff. Soil survey field and laboratory methods manual. Soil Survey Investigations Report 51(2.0) Soil Survey Staff (ed). U.S. Department of Agri. Natural Resources Conservation Service

Chapman HD (1965) Cation exchange capacity. In: CA Black, Ensminger LE, and FE. p 1569

Day PR (1965) Hydrometer method of particle size analysis. In: Black CA (ed) Methods of soil analysis. Agron, Mumbai, pp 562-563

Elias E (2016) Soils of Ethiopian high lands: geomorphology and properties. CASCAPE project, ALTERA. Wageningen University and Research Centre, Wageningen, p 385

Emiru N, Gebrekidan H (2013) Effect of land use changes and soil depth on soil organic matter, total nitrogen and available phosphorus contents of soils in senbat Watershed, Western Ethiopia. Asian Res Publ Netw J Agric Biol Sci 8(3):206-212

EMS (2017) Ethiopian meteorological service data base (2007-2016). Ethiopian Meteorological Service, Addis Ababa

Getachew F, Abdulkadir A, Lemenih M, Fetene A (2012) Effects of different land uses on soil physical and chemical properties in Wondo Genet area, Ethiopia. NY Sci J 5:110-118

Getahun H, Mulugeta L, Fisseha I, Feyera S (2014) Impacts of land use changes on soil fertility, carbon and nitrogen stock under smallholder farmers in central highlands of Ethiopia: implication for sustainable agricultural landscape management around Butajira area. N Y Sci J 7(2):27-44

Gomez KA, Gomez A (1984) Statistical procedure for agricultural research, 2nd edn. Wiley, New York, p 680

Habtamu A, Heluf G, Bobe B, Enyew A (2014) Fertility status of soils under different land uses at Wujiraba watershed North-western highlands of Ethiopia. Agric For Fish. https://doi.org/10.11648/j.aff.20140305.24

Hazelton P, Murphy B (2007) Interpreting soil test results: what do all the numbers mean?, 2nd edn. CSIRO Publishing, Collingwood, p 152

Hillel D (1980) Fundamentals of soil physics. Academic Press, New York, p 413

Hurni H, Abate S, Bantider A (2010) Land degradation and sustainable land management in the highlands of Ethiopia. In: Hurni H, Wiesmann $\mathrm{U}$ (eds) Global change and sustainable development: a synthesis of regional experiences from research partnerships. University of Bern, Bern, pp 187-207

Jackson ML (1979) Soil chemical analysis: advanced course, 2nd edn. Department of Soils, College of Agric., University of Wisconsin, Madison

Kakaire J, Makokha GL, Mwanjalolo M, Mensah AK, Menya E (2015) Effects of mulching on soil hydro-physical properties in Kibaale Sub-catchment, South Central Uganda. Appl Ecol Environ Sci 3(5):127-135

Kemper WD, Rosenau RC (1986) Aggregate stability and size distribution/ method of soil analysis, Part 1: physical and mineralogical methods, Agronomy Monograph No. 9, ASA-SSA-Madison USA, pp 425-442

Khan F, Hayat Z, Ahmad W, Ramzan M, Shah Z, Sharif M, Mian IA, Hanif M (2013) Effect of slope position on physicochemical properties of eroded soil. Soil Environ 32(1):22-28 
Kizilkaya R, Dengiz O (2010) Variation of land use and land cover effects on some soil physico-chemical characteristics and soil enzyme activity. Zemdirb Agric 97(2):15-24

Klute A (1965) Water holding capacity. In: Black CA (ed) Methods of soil analysis. No. 9. Part I. American Society of Agronomy, Madison, pp 273-278

Kotingo KE (2015) Toposequence analysis of soil properties of an agricultural field in the Obudu mountain slopes, Cross River State-Nigeria. Eur J Phys Agric Sci 3(1): ISSN 2056-5879

Landon JR (ed) (1991) Booker tropical soil manual: a handbook for soil survey and agricultural land evaluation in the tropics and subtropics. Longman Scientific and Technical, Essex, New York, p 474p

Lawal BA, Tsado PA, Eze PC, Idefoh KK, Zaki AA, Kolawole S (2014) Effect of slope positions on some properties of soils under a Tectona grandis plantation in Minna, Southern Guinea Savanna of Nigeria. Int J Res Agric For 2014(1):37-43

Lechisa T, Achalu C, Alemayehu A (2014) Dynamics of soil fertility as influenced by different land use systems and soil depth in West Showa Zone, Gindeberet District, Ethiopia. Agric For Fish 3:489-494. https://doi.org/10.11648 /j.aff.20140306.18

Musa H, Gisilanbe SA (2017) Differences in physical and chemical properties of soils on Yelwa-Dobora toposequence in Ganye local government area, Adamawa State, Nigeria. Sky J Soil Sci Environ Manag 6(1):011-018

Olsen SR, Cole CV, Watanabe FS, Dean LA (1954) Estimation of available phosphorus in soil by extraction with sodium bicarbonate. USDA Circ 939:1-19

Osuaku SK, Ukaegbu EP, Poly-Mbah CP, Nnawuihe CO, Okoro GO, Osuaku HE (2014) Variability in some physical and chemical properties of soil along a toposequence in Alvan Ikoku Federal College of Education, Owerri, Imo State, Nigeria. Int J Res Appl Natl Soc Sci 2014:17-24

Peach M (1965) Hydrogen ion activity. Methods of soil analysis. Soil Science Society of America, Madison, pp 374-390

Rowell DL (1994) Soil science: methods and applications. Addison Wesley Longman Limited, England, p 350

Safadoust A, Doaei N, Mahboubi AA, Mosaddeghi MR, Gharabaghi B, Voroney P, Ahrens B (2015) Long-term cultivation and landscape position effects on aggregate size and organic carbon fractionation on surface soil properties in semi-arid region of Iran. Arid Land Res Manag 30(4):345-361. https://doi.org/10.1080/15324982.2015.1016244

Salako FK, Tian G, Kirchhof G, Akinbola GE (2006) Soil particles in agricultural landscapes of a derived savanna in southwestern Nigeria and implications for selected soil properties. Geoderma 137:90-98

Selassie YG, Anemut F, Addisu S (2015) The effects of land use types, management practices and slope classes on selected soil physico-chemical properties in Zikre watershed, North-Western Ethiopia. Environ Syst Res 4:3

Sertsu S, Bekele T (2000) Procedure for soil and plant analysis. National Soil Research Centre, Ethiopian Agricultural Research Organization, Addis Ababa

Sumner ME, Stewart BA (1992) Soil crusting: chemical and physical processes, 1st edn. Lewis Publishers, Boca Raton, p 372

Tadele A, Aemro T, Yihenew G, Birru Y, Wolfgramm B, Hurni H (2013) Soil properties and crop yields along the terraces and toposequece of Anjeni watershed, Central Highlands of Ethiopia. J Agric Sci 5(2):134-144
Tan KH (1996) Soil sampling, preparation, and analysis. Marcel Dekker, New York

Taye G, Poesen J, Van Wesemael B, Vanmaercke M, Teka D, Deckers J, Goosse T, Maetens W, Nyssen J, Hallet V, Haregeweyn N (2013) Effects of land use, slope gradient, and soil and water conservation structures on runoff and soil loss in semi-arid Northern Ethiopia. Phys Geogr 34(3):236-259. https //doi.org/10.1080/02723646.2013.832098

Tellen VA, Yerima BPK (2018) Effects of land use change on soil physicochemical properties in selected areas in the North West region of Cameroon. Environ Syst Res 7:3. https://doi.org/10.1186/s40068-018-0106-0

Thomas GW (1990) Exchangeable cations. In: Page L, Miller R, Keeney R (eds) Methods of soil analysis, Part 2. American Society of Agronomy, Madison, pp 159-166

Tsehaye G, Mohammed A (2013) Effects of land-use/cover changes on soil properties in a dryland watershed of Hirmi and its adjacent agro ecosystem: Northern Ethiopia. Int J Geosci Res 1:45-57

van Reeuwijk L (2006) Procedures for soil analysis, 6th edn. International Soil Reference and Information Centre (ISRIC), Wageningen

Walkley A, Black CA (1934) An examination methods for determining soil organic matter and the proposed modification of the chromic acid titration method. Soil Sci 37:29-38

Wang J, Fu BJ, Qiu Y, Chen LD (2001) Soil nutrients in relation to land use and landscape position in the semi-arid small catchments on the Loess Plateau in China. J Arid Environ 48:537-550

Wolde M, Veldkamp E, Mitiku H, Nyssena J, Muys B, Kindeya G (2007) Effectiveness of exclosures to restore degraded soils as a result of overgrazing in Tigray, Ethiopia. J Arid Environ 69:270-284

Worku G, Bantider A, Temesgen H (2014) Effects of land use/land cover change on some soil physical and chemical properties in Ameleke microwatershed Gedeo and Borena Zones, South Ethiopia. J Environ Earth Sc 4:13-24

Wube MA, Assen M (2019) Effects of land cover changes and slope gradient on soil quality in the Gumara watershed, Lake Tana basin of NorthWest Ethiopia. Model Earth Syst Environ 2020(6):85-97. https://doi. org/10.1007/s40808-019-00660-5

Yimer F, Ledin S, Abdulakdir A (2007) Changes in soil organic carbon and total nitrogen contents in three adjacent land use types in the Bale Mountains, southeastern highlands of Ethiopia. For Ecol Manag 242:337-342

Yimer F, Ledin S, Abdulakdir A (2008) Concentrations of exchangeable bases and cation exchange capacity in soils of cropland, grazing and forest in the Bale Mountains, Ethiopia. For Ecol Manag 256:1298-1302. https://doi. org/10.1016/j.foreco.2008.06.047

Young A (1976) Tropical soils and soil survey. Cambridge University Press, London, p 468

Ziadat FM, Taimeh AY (2013) Effect of rainfall intensity, slope and land use and antecedent soil moisture on soil erosion in an arid environment. Land Degrad Dev 24:582-590

\section{Publisher's Note}

Springer Nature remains neutral with regard to jurisdictional claims in published maps and institutional affiliations.

\section{Submit your manuscript to a SpringerOpen ${ }^{\circ}$ journal and benefit from:}

- Convenient online submission

- Rigorous peer review

- Open access: articles freely available online

- High visibility within the field

Retaining the copyright to your article

Submit your next manuscript at springeropen.com 